\section{Det er aldri for sent å bli fysisk aktiv!}

Både å fortsette med fysisk aktivitet og å starte med å være fysisk aktiv etter 70 års alder er assosiert med lavere hjelpbehov og dødelighet, viser en israelsk studie.

Studien fulgte til sammen 1861 personer i tidsrommet 1980-2008. Alle deltakerne var født i 1920 eller 1921, og studiens endepunkter var dødelighet av alle årsaker, så vel som grad av hjelpbehov (1).

De som var fysisk aktive ved 70 års alder, hadde signifikant lavere dødelighet ved alle senere kontroller sammenliknet med de fysisk inaktive. Tidligere fysisk inaktive som startet en fysisk aktiv livsstil mellom 78 og 85 års alder hadde også signifikant lavere dødelighet og lavere grad av hjelpbehov ved studieslutt.

- Fysisk aktivitet er billig og uten bivirkninger. I et folkehelseperspektiv har denne studien viktige konklusjoner, særlig det forhold at det gir helsegevinster å starte opp med fysisk aktivitet selv i høy alder, sier Olaf Sletvold, som er professor og overlege i geriatri ved St. Olavs hospital.

- Fortsatt gjenstår det å avklare om det for de aller eldste finnes en lavest effektiv «dose», eller om det er slik at «jo mer, jo bedre». Dessverre var metoden for registre-

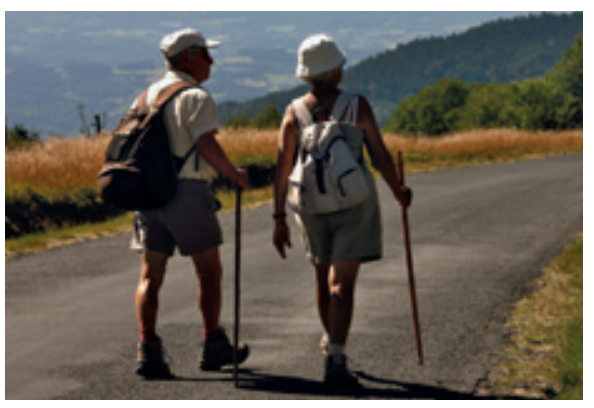

Illustrasjonsfoto Colourbox

ring av fysisk aktivitet ikke validert. Dette i motsetning til i en nylig publisert studie fra HUNT om forebygging av død pga. hjerte- og karsykdommer, der det faktisk også kunne påvises en dose-respons-sammenheng (2), sier Sletvold.

\section{Are Brean}

are.brean@siv.no

Tidsskriftet

\section{Litteratur}

Stessman J, Hammerman-Rozenberg R, Cohen A et al. Physical activity, function, and longevity among the very old. Arch Intern Med 2009; 169: 1476-83.

2. Tjønna AE, Nilsen TI, Slørdahl SA et al. The association of metabolic clustering and physical activity with cardiovascular mortality: the HUNT study in Norway. J Epidemiol Community Health 2009 e-publisert 6.8. doi: 10.1136/jech.2008.084467.

\title{
Søvnapnésyndrom bedres ved vekttap
}

\section{Vekttap er assosiert med signifikant bedring av obstruktiv søvnapné- syndrom hos overvektige pasienter med type 2-diabetes, viser ameri- kansk multisenterstudie.}

Det har hittil vært sparsomt empirisk belegg for antakelsen om at vekttap fører til bedring av symptomene ved obstruktiv søvnapné. I denne studien ble 264 pasienter med overvekt, type 2-diabetes og obstruktiv søvnapné-syndrom randomisert til enten intensiv livsstilsbehandling eller intensivert diabetesoppfølging (1). I gruppene ble det registrert et gjennomsnittlig vekttap etter ett år på henholdsvis $11,1 \mathrm{~kg} \mathrm{og} 0,5 \mathrm{~kg}$ $(\mathrm{p}<0,001)$.

Etter dette året hadde mer enn tre ganger så mange av pasientene som gjennomgikk livsstilsbehandling, ikke lenger obstruktiv søvnapné-syndom, sammenliknet med gruppen som kun fikk diabetesoppfølging $(13,6 \%$ mot 3,5\%). Prevalensen av alvorlig søvnapnésyndrom blant gruppen som fikk livsstilsbehandling var halvparten så høy som i den andre gruppen (18,4\% sammenliknet med 37,9\%).

- Resultatene støtter hypotesen om en sammenheng mellom fedme, diabetes og obstruktiv søvnapné, sier Jøran Hjelmesæth, som er senterleder ved senter for sykelig overvekt i Helse Sør-Øst.

- Selv om intensiv livsstilsbehandling reduserte alvorlighetsgraden av søvnapné med omtrent $20 \%$, hadde over halvparten av pasientene moderat til alvorlig søvnapné ved slutten av studien. Det er derfor bekymringsfullt at bare $5 \%$ ble behandlet med pustemaske (CPAP). Fremtidige studier bør avklare eventuelle tilleggseffekter av kraftigere vektreduksjon, for eksempel etter fedmekirurgi, og CPAP-behandling, sier Hjelmesæth.

\section{Are Brean}

are.brean@siv.no

Tidsskriftet

\section{Litteratur}

Foster GD, Borradaile KE, Sanders MH et al. A randomized study on the effect of weight loss on obstructive sleep apnea among obese patients with type 2 diabetes. The Sleep AHEAD Study. Arch Intern Med 2009; 169: 1619-26.

\section{Sekvensering av et humant} genom fra et enkelt molekyl

$V i$ vet i dag mye mer om det humane genom enn for få år siden, og metodene for sekvensering av DNA er blitt mer nøyaktige og mer effektive. En amerikansk forskergruppe har nå forbedret metodene ytterligere, og rapporterte nylig enkeltmolekylsekvensering (Nat Biotechnol 2009; 27: 847-50).

Forskergruppen sekvenserte det humane genom uten å benytte kloning, amplifisering eller ligering, og påviste ca. 2,8 millioner enkeltnukleotidpolymorfismer. De validerte resultatene sine ved å analysere med Sanger-sekvensering, og fant at kun $1 \%$ var falskt positive. I artikkelen beskrives 752 regioner med kopitallvariasjon, og 27 av disse ble bekreftet med polymerasekjedereaksjon.

\section{Tynne lår øker risiko for hjerte- og karsykdom}

Studier antyder at både lav og høy kroppsmasseindeks er assosiert med tidlig død. Nå har danske forskere sett på sammenhengen mellom omkretsen på låret og hjerte- og karsykdom og dødelighet (BMJ 2009; 339: b3292).

I en prospektiv studie ble 1436 menn og 1380 kvinner fulgt opp i ti år for hjerteog karsykdom og i 12,5 år for totaldødelighet. En liten låromkrets var forbundet med $ø$ kt risiko for hjerte- og karsykdom og for tidlig død for både kvinner og menn. En omkrets på mindre enn $60 \mathrm{~cm} ø k$ te risikoen for tidlig død i betydelig grad. Resultatene var uavhengig av abdominal og generell overvekt, livsstil, blodtrykk og lipidkonsentrasjon. Den negative effekten av tynne lår kan være relatert til liten muskelmasse.

\section{Personlighetstype og dødsrisiko}

Type D-personlighet (den bekymrede type) har vist seg som en uavhengig risikofaktor for kardial død (Arch Surg 2009; 144: 728-33). I en nederlandsk pilotstudie undersøkte man med henblikk på en mulig sammenheng også for dødsfall ved perifer arteriell sykdom.

184 pasienter med symptomatisk perifer karsykdom ble personlighetstestet og fulgt opp over fire år. 16 pasienter $(8,7 \%)$ døde. Etter justering for alder, diabetes og nyresykdom, viste type $D$-personligheter fortsatt en tredoblet risiko for død (OR 3,5; $95 \%$ KI 1,1-11,1). 